\title{
Emptiness in psychological science and practice
}

\author{
Joaquim Quintino-Aires \\ Instituto Vegotsky de Lisboa, Lisboa, Portugal \\ Corresponding author. E-mail: quintino.aires@gmail.com
}

\begin{abstract}
Psychology is now one of the most popular sciences for young students. But whether academic production or professional practice, it is still in crisis. When we look together at two different approaches we realize the enormous amount of syncretism. They are not only two different approaches to the same science. They are more than that, they are different areas of knowledge, with very different practical implications. Discussion of psychology with the other sciences researching the same "objects" is nonexistent. So when it comes to practice, many of young psychologists leave the profession.

This article is an invitation to colleagues for a "look inside" this interesting science that can make a significant contribution to human sciences and the better life of human beings in the 21st century. This call is supported by a re-reading of the text by Lev S. Vygotsky The historical meaning of the crisis in psychology written in 1927. The article is structured in four subtopics: the problem of general science (in Psychology), the problem of terminology, the problem of difficulty in recognizing the crisis and the problem of emptiness. Being a call, of course, it is not a complete and finished analysis. It is rather a desire that, engaging some colleagues, we can continue the dialogue with Vygotsky on this topic started by him ninety years ago.
\end{abstract}

Keywords: psychology, crisis, approaches, general science, dialogue, Vygotsky

The stone the builders rejected, Has become the cornerstone...

This afternoon, after a long period of work, and as in other years after our meetings, many of my exhausted colleagues said: "Oh, it is the same; tomorrow is another long day of work". And I said, as I usually do, "Yeah! Tomorrow is another day of work. Yes!" I reacted in that way because I really like what I do. But I am certain that the reason I really like to do what I do is not just because I am a psychologist, but because someone introduced me to a dialogue with Lev Vygotsky.

I would like to share with you a little bit of my story as a psychologist. In 1991, I had a very good position. At that time it was difficult to get work as a psychologist in Portugal, and even harder if you were a clinical psychologist. Nevertheless, I had 
the opportunity to work as a psychologist at the Laboratory of Neuropsychology of the Department of Neurosurgery at the Lisbon Military Hospital. I must say that I was fortunate to be in this position since this was a very desirable position, available only to the lucky few. Everybody wanted this position. Yet, this was not really what I was looking for.

I remember the day I visited my director and told him about my desire to leave the hospital, because I did not like what I was doing there. He disagreed with me, but I affirmed my view and said: "I do not regret my decision to leave because this job does not give me professional satisfaction." He told me, "Ok, you are very young [he was a military neurosurgeon higher up than me], so go to Barcelona to be trained in Psychology from another perspective. Subsequently, you will decide what to do in your professional life." As a result, after studying historical cultural neuropsychology, the Vygotsky-Luria-Leontev approach, I found my love in Psychology. And each day I am still in dialogue with Vygotsky.

My report is very simple, but it has a strong meaning for me. I will share with you my last reading of a text by Vygotsky, which I have revisited several times. It is "The Historical Meaning of the Crisis in Psychology," written in 1927. I especially want to present some sentences from this book, in hopes of provoking you in the way I was provoked. I have organized the report under four topics: The problem of general science (in Psychology); the problem of terminology; the difficulty in recognizing the crisis; and the problem of emptiness.

\section{The problem of general science}

- "Psychology is pregnant with a general theory, but has not yet given birth."

- "A general science is a science that receives material from a variety of particular disciplines, and then prepares and subsequently generalizes them, a process impossible within each separate discipline."

- "Unity is achieved through subordination and dominion, through the fact that particular disciplines renounce their sovereignty in favor of a general science."

There is a belief that our branch of science encompasses a great number of professionals, but unfortunately, the only thing many psychologists have in common is sympathy for people. This makes dialogue among different psychologists impossible. Sometimes it is much easier for a psychologist to speak with a biologist than for psychologists to conduct a dialogue among themselves.

- "When various disciplines have a tendency to develop into a general science and extend their influence to adjacent areas of study, a general science arises from the need to unite heterogeneous branches of knowledge. "

We must work harder and more courageously in order to produce a General Psychological Science, as Vygotsky invites us to do.

- "A general science happens to be distinguished from a particular discipline, not because it has a broader scope, a higher content, but because it is qualitatively differently organized". 
But the problem is that, even if we are specialists in dialogue, in relationships, and in communication - and we can find thousands of psychologists who work only on dialogue, communication, and relationships - we still act like a group of people sitting in a circle, each looking away, i.e., neither looking at nor seeing each other.

I remember a conference on psychotherapy held in 1992 in Lisbon, where the organizing committee had invited all groups represented in Portugal. Each approach - psychoanalytic, cognitive-behavioural, humanistic, etc. - was present. I was absolutely shocked by the fact that they formed separate groups of each discipline. In each room there were only professionals from one approach. No dialogue, only monologue! In my view, we're still taking the same approach.

Of course, we need to learn to work as people in a circle toward the midpoint, watching and listening to others and dialoguing, or creating a General Science will be impossible, unlike what has happened with the other sciences.

"But this debate has been impossible. The important thing is to beat the opponent; no one wants to waste time studying it [his point of view]".

\section{The problem of terminology}

The problem of terminology is another serious problem in psychology. For example, if we use the term "cognitive," note the number of different meanings that we'll be using.

- "If someone wanted to build a clear and objective picture of the situation in psychology today, ... suffice it to study the psychological language, its nomenclature and terminology, the vocabulary and syntax of the psychologist".

- "The highly developed and precise language of modern physics, chemistry, physiology (not to mention math ...) started being formed and perfected at the same time each of these sciences developed, and this did not happen in any way spontaneously, but was produced consciously under the influence of tradition, criticism, and terminological creativity coined by their own societies and scientific congresses".

We can illustrate this with the case of the Sociedade Portuguesa de Psicologia, founded in 1960, which has had a scientific journal since 1967, and even been the force behind current laws since 1978. But if we ask a Portuguese psychologist, we will find that a great many professionals (at least 99\%) do not know that this society exists. Of course, there are dozens of societies and associations oriented to each of the psychotherapy approaches, and psychologists working in psychotherapy know them, but the Portuguese Psychological Society is practically unknown.

So we still produce, write, and speak unclearly and confusingly, in an ambiguous language, using multi-semantic terms and vague ideas as well. To summarize this issue, we can say that bilingualism persists within psychology, and psychologists do not know different languages, only their own. And to cite the German poet Wolfgang Goethe: "Those who known nothing of foreign languages know nothing of their own". 


\section{The difficulty in recognizing the crisis}

- "Science is not a dead entity, finished, immobile, comprised of preset principles..."

- "But a living system, constantly evolving and advancing the stated facts, laws, assumptions, structures and conclusions without interruption..."

- "Criticized, proven, partially rejected, interpreted, and organized again, etc."

In my opinion, this is really the more complex issue. It leads us to Bella Kotik's earlier words about Jerome Bruner, who, during a trip to Moscow, started a speech by saying he was very happy to present his ideas to a group which can criticize his work. This is highly clever and honest. But in our current reality, as in the past, Vygotsky observed,

"The important thing is to beat the opponent; no one wants to waste time studying it".

Agreeing with N.N. Lange (1914), Vygotsky emphasizes in this text his idea of the lack of a universally recognized system of science. Each author is a system. In my view, Christians, Evangelicals, Catholics, the Orthodox, and psychologists share a common aspect, which is Narcissism. Each "science" professes its own vanity. And the result is that psychology as a general science does not exist.

Psychology is somewhere between Biology and Sociology, i.e., not a science in itself. And it is amazing that over the last years, maybe the last 20 years, we can testify to this reality becoming stronger and stronger. In fact, there is a lack of psychology in psychology. If we look at the programs for psychology in the universities, we will realize that they are designed closer to Biology or Sociology than to Psychology itself. We have started psychological work, but have not yet established its fundamental principles.

Take the example of behaviorism. Some of the pillars of this branch of psychology were confused about what they really wanted. Are they talking about the same or different paradigms?

\section{J.B. Watson (1878-1950)}

- (1913) Psychology as the behaviorist views it. Psychological Review, 20, 158177.

\section{Clark Leonard Hull (1884-1952)}

- (1934) The concept of the habit-family hierarchy and maze learning: Part 1. Psychological Review, 41, 33-54.

\section{Edward Ch. Tolman (1886-1959)}

- (1948) Cognitive maps in rats and men. The Psychological Review, 55(4), 189-208.

\section{B.F. Skinner (1904-1990)}

- (1974) About Behaviorism.

A critical look at behaviorism is quickly emerging: 


\section{A- The issue of the category of Mind}

- "Cognition" as its awkward substitute

- Tolman vs. Hull debate

\section{B- The question of method (experimental introspection)}

- Inventories, questionnaires, and other self-assessment tools.

\section{C- The issue of conditioned reflex theory (I. Pavlov) as substance of behav- iorism}

- Reflex theory is not applicable to the study of human behavior due to the secondary receptor system. Language introduces subjectivity (I. fPavlov, 1924).

\section{D- The issue of the closing of K. Lashley's laboratory in 1959}

Several investigations had results contrary to his theory.

In a 1985 work, J.J. White looked at the manuals used in United States universities for the study of cognitive psychology. The seven most used manuals disagree on basic ideas.

- $\quad$ Seven manuals disagree on basic ideas.

- Of 3,246 publications cited, only 19 (0.6\%) had basic ideas shared by all.

- Only 146 (4.5\%) shared basic concepts in at least three books.

- Few phenomena were included in all the books.

- The same concepts were given different names.

If we go back in time, we will be quite surprised by what was written when psychology was first beginning to be applied to Information Processing Theory.

- (Herbert Simon, 1957) In 10 years psychological theories will be written as computer programs ...;

- (Herbert Simon, 1969) In 20 years, computers will do everything that humans do....

In 2004 a very interesting book was published in Portugal (but it could have been in any other country). The book is Cognitive Therapies: Theories and Practices, by Oscar Gonçalves. In the first part of the book, dedicated to theoretical foundations, the author presents a theory of information processing in humans. In the second part, the book is dedicated to the practice of cognitive therapy. Over and over, the theory of information processing and cognitive therapy are both described by the adjective "cognitive"; but the two have nothing to do with one another. At the university where I graduated in psychology, the difference between the two approaches was so great that we felt that many teachers in one department did not relate to teachers from the other. Yet the book was very successful, and no one seemed concerned with the syncretism in it! 


\section{The problem of emptiness}

In order to get my professorship, I worked on a project for 17 years. My topic was to show the impossibility of an innate organ for language, contrary to what had been proposed by N. Chomsky. Near the end of the project, all of my colleagues told me that my project would excite no interest because scientists had already discovered the gene for language. Since I was not convinced, I went back to university as an undergraduate to study molecular biology and genetics. This was important, because I had the opportunity to learn that the so-famous FOXP2, referenced since 2001, was only a transcription factor for the gene CNTNAP2, and that it had nothing specifically to do with language, since it served all complex motor learning both in human and in other species, like birds. Despite this fact, FOXP2 is referred to as the gene for language by psychologists. And psychologists quickly lost interest in psychological theories of language.

My last work as an undergraduate Molecular Biology and Genetics student naturally focused on FOXP2. In all the scientific publications correlating FOXP2 and language written by biologists, I never found any reference to the extensive literature that exists on the psychology of language, nor psycholinguistics. For biologists, the psychology of language and psycholinguistics did not exist. The only reference that can be considered more or less close to the psychology of language in all of these scientific articles in the 21st century, appeared in one article referencing the A Treatise of Human Nature by David Hume from the 18th century. Due to lack of organization, psychology is omitted from the process of constructing knowledge, even on issues such as language.

During the time I was an undergraduate Molecular Biology and Genetics student, I attended molecular biology and genetics conferences. At one of these conferences a report which associated "molecular genetics" and "intellectual disability" caught my attention. The study reported that a different gene sequence alone caused a change in the movement of a nematode, $C$. elegans, by creating malformation of the nervous system. When questioned about the "magic flight" from this study on nematodes to intellectual disability in humans, the authors replied that human intelligence needs the nervous system. This is true, but I think it's just as true that the construction of knowledge about intellectual disability needs psychologists.

One of the hallmarks of a psychologist is the use of tests. Tests need to be adapted for use in new populations. Obviously, this is important work, and it takes thousands of hours of work. So I imagine that when someone starts to adapt a test, first he/she studies what is written about that test. The first neuropsychological battery adapted to the Portuguese population was the Luria-Nebraska Neuropsychological Battery. More than 20 years after the publication of scientific articles criticizing the conceptual construction of this test, it is clear that the attempt to build a theory of psychology occurs without dialogue, in an autistic manner.

This method of building a theory of psychology and working on it, or without it, causes the emptiness that psychologists feel. Today thousands of young people are interested in this beautiful and important science, but not because they imagine they will appreciate studying it. They say they are good counsellors, and friends often seek them out to chat. Talk! Just talk! And the truth is that when they get 
to study psychology, post-graduate and even undergraduate programs guide these students toward Reiki, meditation, etc., or other strange techniques that resemble the training of dogs, horses, and other animals without language. I have nothing against that! All practices are welcome. But this is not psychology. Let's not confuse the objects or methods, and what we're talking about: Psychology as a science and as a profession should be far beyond that.

All this leads me to think that, 90 years after Vygotsky's "The Historical Meaning of the Crisis in Psychology", a dialogue with the author of that text is still very current and necessary. Perhaps we can even say it's mandatory. And certainly it will cause many more to be happy with our work, because then we can see the product of what we do with Psychology, with a new practice of psychological work.

\section{References}

Gonçalves, Ó. F. (2004). Terapias cognitivas: Teorias e práticas [Cognitive therapies: Theories and practices]. Lisboa: Edições Afrontamento, Porto.

Quintino-Aires, J. (2007). Processamento da fala no hemisfério cerebral direito e o problema da génese da linguagem [Speech processing in the right cerebral hemisphere and the problem of the genesis of language]. Tese doutoramento (Doctoral thesis), Universidade Nova de Lisboa.

Quintino-Aires, J. (2014). FOXP2 e linguagem - uma revisão [FOXP2 and language - A review]. Lisboa: ISCSEM, Laboratório de Biologia Molecular.

Simon, H. (1957). Models of man. New Jersey: John Wiley.

Simon, H. (1969). The sciences of the artificial. Cambridge: MIT Press

Vygotsky, L. S. (2011). El significado histórico de la crisis de la psicología. Una investigación metodológica [The Historical Meaning of The Crisis in Psychology: A Methodological Investigation]. Obras escogidas [Selected works]. (Vol. 1, pp. 257-407). Madrid: Visor. (Original work published 1927)

White, J. J. (1985). On the status of cognitive psychology. American Psychologist, 40, 117-119. doi: 10.1037/0003-066X.40.1.117 